\title{
Effects of Autoantibodies to the Insulin Receptor on
}

\section{Isolated Adipocytes}

\author{
STUDIES OF INSULIN BINDING AND INSULIN ACTION
}

\author{
C. Ronald Kahn, Kathleen Baird, Jeffrey S. Flier, and David B. \\ JARRETT, Diabetes Branch, National Institute of Arthritis, Metabolism, \\ and Digestive Diseases, National Institutes of Health, Bethesda, \\ Maryland 20014
}

\begin{abstract}
A B S T R A C T Autoantibodies to the insulin receptor have been detected in the sera of several patients with the Type B syndrome of insulin resistance and acanthosis nigricans. In this study we have used three of these sera (B-1, B-2, and B-3) as probes of the insulin receptor in isolated rat adipocytes. Preincubation of adipocytes with each of the three sera resulted in an inhibition of subsequent $\left[{ }^{125} \mathrm{I}\right]$ insulin binding. $50 \%$ inhibition of binding occurred with serum dilutions of 1:5 to 1:7,500. As in our previous studies with other tissues, Scatchard analysis of the insulin-binding data was curvilinear consistent with negative cooperativity. Computer analysis suggested that in each case the inhibition of binding was due to a decrease in receptor affinity rather than a change in available receptor number.

In addition to the effects on insulin binding, adipocytes pretreated with antireceptor sera also showed alterations in biological responses. All three sera produced some stimulation of basal glucose oxidation. With serum B-3, maximal stimulation of glucose oxidation occurred at a serum concentration that inhibited binding by only $10-15 \%$, whereas with serum B-2 the dilution curves for inhibition of binding and stimulation of glucose oxidation were superimposable. Serum B-1 behaved as a partial agonist; that is, it inhibited binding more effectively than it stimulated glucose oxidation. Cells pretreated with this serum in a concentration which inhibited binding by $80 \%$ also showed a five-fold shift to the right in the dose response of insulin-stimulated glucose oxidation, whereas sperminestimulated glucose oxidation was unaffected. Serum B-2, which contained the highest titer of antireceptor
\end{abstract}

This work was presented in part at the 36th Annual Meeting of the American Diabetes Association, 20-22 June 1976, San Francisco, Calif.

Received for publication 16 December 1976 and in revised form 5 July 1977. antibodies, also stimulated 2-deoxy-glucose transport, as well as glucose incorporation into lipid and glycogen.

Both the ability of the serum to inhibit binding and stimulate glucose utilization were enriched in purified immunoglobulin fractions and retained in the $F\left(a b^{\prime}\right)_{2}$ fragment of the IgG. In addition, the bioactivity was blocked by antihuman IgG but not by anti-insulin antibodies. Enzymatic digestion of adipocytes with trypsin resulted in a complete loss of insulin-stimulated bioactivity of serum B-3, but had only minor effects on the glucose oxidation produced by serum B-1 or B-2.

These data suggest that the antibodies present in these three sera bind to different determinants on the insulin receptor. Thus, these antibodies may be useful probes of receptor structure and function.

\section{INTRODUCTION}

We have recently described several patients with two clinical syndromes characterized by marked insulin resistance and the skin disorder acanthosis nigricans (1). In the Type A form of these syndromes, the insulin resistance and acanthosis nigricans occurred in young females with signs of virilization, whereas in Type B these findings occurred in older patients with signs of an immunologic disorder. The insulin resistance in both Type A and B patients was associated with a marked decrease in insulin binding to its receptor sites. Furthermore, the sera of the Type B patients contained inhibitors which could reproduce this receptor defect in vitro using normal cells (2). These inhibitors of insulin receptor function were shown to be antibodies directed at the insulin receptor (3).

In the present study, we have investigated the effects of three sera containing anti-insulin receptor antibodies on isolated rat adipocytes. With these cells, all three sera inhibited insulin binding but produced var- 
ying effects on glucose utilization. The quantitative relationship between the ability of a serum to inhibit insulin binding and to stimulate glucose oxidation, both in normal and trypsin-treated cells, suggests that these antibodies bind to different determinants on the receptor. Pretreatment of cells with the one serum which had little stimulating activity resulted in a competitive inhibition of insulin-stimulated glucose oxidation. These findings suggest that these sera will be useful probes of both insulin binding and action.

\section{METHODS}

Materials. Porcine insulin (Lot 7GUHSL) was purchased from Elanco Products Co., Indianapolis, Ind.; bovine serum albumin (Fraction V, Lot N53309) from Armour and Co., Chicago, Ill.; and crude collagenase (CLS45K137), trypsin ( $2 \times$ crystallized), lima bean trypsin inhibitor, and neuraminidase derived from Clostridium perfringens from Worthington Biochemical Corp., Freehold, N. J. Guinea pig anti-insulin antibody was purchased from Dr. Peter Wright, and rabbit antihuman IgG was purchased from Behring Diagnostics, American Hoechst Corp., Somerville, N. J. The 2-deoxy-D- $\left[1-{ }^{14} \mathrm{C}\right]$ glucose and D$\left[\mathrm{U}-{ }^{14} \mathrm{C}\right] \mathrm{glucose}$ was purchased from New England Nuclear, Boston, Mass. [125I]Insulin was prepared by a modification of the chloramine-T method $(4,5)$ to specific activities of $100-$ $200 \mu \mathrm{Ci} / \mu \mathrm{g}$ or $0.3-0.6$ atoms of ${ }^{125} \mathrm{I}$ per insulin molecule. It has previously been demonstrated that under these conditions most of the insulin is monoiodinated and retains full biological activity.

Preparation of isolated adipocytes. Male Sprague-Dawley rats $(100-180 \mathrm{~g})$ were used for all experiments. All studies were performed in the morning on animals which had free access to standard Purina rat chow. Animals were anesthetized with ether and decapitated, and the epididymal fat pads were removed. The fat pads were cut into several pieces and digested at $37^{\circ} \mathrm{C}$ with gentle shaking in Krebs-Ringer bicarbonate $(\mathrm{KRB})^{1}$ buffer containing $2 \mathrm{mg} / \mathrm{ml}$ collagenase. The KrebsRinger bicarbonate buffer used in all experiments contained $118 \mathrm{mM} \mathrm{NaCl}, 5 \mathrm{mM} \mathrm{KCl}, 1.3 \mathrm{mM} \mathrm{CaCl}, 1.3 \mathrm{mM} \mathrm{MgSO}_{4}$, $1.2 \mathrm{mM} \mathrm{KH}_{2} \mathrm{PO}_{4}$, and $25 \mathrm{mM} \mathrm{NaHCO}$. The $\mathrm{pH}$ was adjusted to 7.4 with $\mathrm{NaOH}$ after the buffer had been equilibrated with $95 \% \mathrm{O}_{2}: 5 \% \mathrm{CO}_{2}$. After $40-60 \mathrm{~min}$ the isolated adipocytes were separated from debris by filtration through a silk screen. The cells were washed three times in a Krebs-Ringer bicarbonate buffer and resuspended in KRB containing $2 \%$ bovine serum albumin (KRB-A).

Bioassays. Glucose oxidation was studied by measuring the conversion of $\left[\mathrm{U}-{ }^{14} \mathrm{C}\right]$ glucose to ${ }^{14} \mathrm{CO}_{2}(6)$. Fat cells from two rats were resuspended in $15 \mathrm{ml}$ of KRB-A;0.2 ml of the cell suspension was added to $1.8 \mathrm{ml}$ of KRB-A containing $0.3 \mathrm{mM}$ glucose and $10 \mu \mathrm{Ci}$ of $\left[\mathrm{U}-{ }^{14} \mathrm{C}\right]$ glucose in polyethylene bottles. The incubation vessels were gassed with $95 \% \mathrm{O}_{2}: 5 \% \mathrm{CO}_{2}$, capped, and incubated in a metabolic shaker at $37^{\circ} \mathrm{C}$ for $2 \mathrm{~h}$. At the end of the incubation period, the contents of the vessels were acidified with $0.3 \mathrm{ml}$ of $2 \mathrm{~N} \mathrm{H}_{2} \mathrm{SO}_{4}$ and the evolved ${ }^{14} \mathrm{CO}_{2}$ collected in $0.2 \mathrm{ml}$ of hyamine hydroxide in hanging wells. All glucose oxidation assays were performed in duplicate or triplicate.

${ }^{1}$ Abbreviations used in this paper: $\mathrm{DBH}$, dopamine- $\beta$ hydroxylase; IDBH, immunoreactive dopamine- $\beta$-hydroxylase; KRB, Krebs-Ringer bicarbonate; KRB-A, KRB with $2 \%$ bovine serum albumin; NSILA-s, nonsuppressible insulinlike activity soluble in acid ethanol.
Glucose incorporation into lipids and glycogen was measured under conditions similar to those for glucose oxidation, except that the concentrations of both labeled and unlabeled glucose were increased ten-fold. At the end of a 2 -h incubation, duplicate $200-\mu \mathrm{l}$ aliquots were taken and the cells were separated from the medium by centrifugation through dinonyl phthalate as described below. The cells were then hydrolyzed in $30 \% \mathrm{KOH}$, and acidified, and total lipids were extracted using a modification of the method of Baruch and Chaikoff (7). $\left[{ }^{14} \mathrm{C}\right]$ glucose incorporation into glycogen was measured using the method of Lawrence et al. (8) with an incubation period of only $20 \mathrm{~min}$ at $37^{\circ} \mathrm{C}$. Both the glycogen and lipid extracts were counted in a scintillation counter. For these experiments, fasted and refed rats were used, since this appeared to increase the fraction of glucose incorporation into lipid and glycogen.

Glucose transport was measured using 2-deoxy-D-[1-14C]glucose (sp act $52 \mathrm{mCi} / \mathrm{mmol}$ ) as described by Olefsky, with minor modification (9). Cells were preincubated with buffer, insulin, or serum fractions for $20 \mathrm{~min}$ at $37^{\circ} \mathrm{C}$ in KRB-A to which $25 \mathrm{mM}$ Hepes had been added. Radiolabeled 2-deoxyglucose was then added to give a final concentration of 0.25 $\mathrm{mmol} /$ liter. Under these conditions, uptake of 2-deoxy-glucose is linear for 4-5 min. After $2 \mathrm{~min}$, duplicate $200 \mu \mathrm{l}$-aliquots were taken and the cells were separated by rapid centrifugation through dinonyl phthalate as described below. The amount of sugar trapped in the extracellular water space was determined with $\left[{ }^{14} \mathrm{C}\right]$ inulin and was less than $10 \%$ of the total stimulated sugar uptake. This was similar to the uptake of 2-deoxy-glucose which occurred in the presence of $50 \mu \mathrm{M}$ cytochalasin B

Binding studies. For comparison with glucose oxidation, all studies of [ $\left.{ }^{125} \mathrm{I}\right]$ insulin binding were performed in the same buffer (KRB-A, pH 7.4) and at $37^{\circ} \mathrm{C}$. The incubation volume was $0.5 \mathrm{ml}$. The cell concentration used was approximately $2 \times 10^{5} \mathrm{cells} / \mathrm{ml}$, and the $\left.{ }^{[125} \mathrm{I}\right]$ insulin concentration was $30 \mathrm{pM}$. Some incubation tubes also contained unlabeled insulin at the concentration indicated in the figures. Under these conditions, [ ${ }^{225}$ I] insulin binding reached a maximum at 15-20 min; this was followed by a gradual decline, presumably due to hormone and receptor degradation. Therefore, all binding studies were carefully timed to this 20 -min period. The incubations were terminated by removing $200-\mu \mathrm{l}$ aliquots from the cell suspension and rapidly centrifuging the cells in $400-\mu$ l plastic microfuge tubes to which $100 \mu \mathrm{l}$ of dinonyl phthalate had been added as described by Gammeltoft and Gliemann (10). The fat cells which form a thin layer on top of the oil were then removed and the cell-bound radioactivity was determined. In all studies, nonspecific binding was considered as the amount of [125I] insulin bound in the presence of $1 \mu \mathrm{M}$ unlabeled insulin. Specific [125I]insulin binding was calculated by subtracting this amount from the total amount of [ $\left.{ }^{125} I\right]$ insulin bound. All binding studies were performed in duplicate.

Procedures for studying serum or antibody effects. In previous studies $(11,12)$ with a variety of other tissues, it had become clear that the binding of antireceptor antibodies to the insulin receptors on cell membranes was of a high affinity and only very slowly reversed. Thus, to study the effects of these sera on adipocytes while minimizing any effect of other serum factors in the incubation, all studies were performed by preincubating fat cells with serum and then washing the cells to remove all serum factors not tightly bound to the cells. In practice, fat cells were incubated with the patient's serum or control serum at the indicated dilutions for $15 \mathrm{~min}$ at $30^{\circ} \mathrm{C}$ and then washed three times in KRB-A before use in the binding or glucose oxidation assays. With this procedure, the effects of endogenous insulin or insulin-like peptides were minimized.

Purified IgG was prepared by DEAE chromatography (13) 
of the ammonium sulfate-precipitated immunoglobulins unless otherwise stated. The bivalent $F\left(a b^{\prime}\right)_{2}$ fragment of the IgG was prepared from the IgG by pepsin digestion (14) and purified by gel filtration on Sephadex G-200. In studies with partially purified immunoglobulin fractions, the wash-out technique described above was not performed.

Enzyme studies. For some studies, fat cells were treated with trypsin or neuraminidase before use in the glucose oxidation. In these experiments the isolated fat cells were incubated with the enzyme at the indicated concentrations in KRB containing $2 \%$ bovine serum albumin for $15 \mathrm{~min}$ at $37^{\circ} \mathrm{C}$. Lima bean trypsin inhibitor was then added to the cells exposed to trypsin (in a concentration equal to that of trypsin on a weight basis), and the cells were then washed three times in KRB-A. When the effect of enzymatic digestion and serum pretreatment were both studied, the enzymatic digestion was always performed first.

Binding data analysis. The data from the binding experiments were analyzed using Scatchard analysis (15). In the present study with adipocytes, as in previous studies from our laboratory with other tissues (16-18), the Scatchard plot was curvilinear and concave upward. From kinetic studies, this appears to be due, at least in part, to negatively cooperative site-site interactions among insulin receptors $(16,17)$. De Meyts and Roth have recently proposed a new quantitative approach to analysis of ligand binding data when cooperativity is present (19). In this analysis, the receptor is assumed to exist in two conformations: a high-affinity conformation at low levels of occupancy and a low-affinity conformation at high levels of occupancy. This high-affinity binding constant has been referred to as $\bar{K}_{e}$ (affinity of the empty receptor); the low affinity binding constant has been referred to as $\bar{K}_{f}$ (affinity of the filled receptor). The ratio of $\bar{K}_{f} / \bar{K}_{e}$ has been termed $\alpha$ and is an interaction factor which is related to the change in free energy associated with the negative cooperativity (20). The average affinity at any level of occupancy is the geometric mean of the fraction of sites with $\bar{K}_{e}$ and $\bar{K}_{f}$.

In the case of the insulin receptor on lymphocytes, liver membranes, and adipocytes, the fall in average affinity due to cooperativity appears to be a simple, linear function of occupancy $(20)$, such that

$$
\frac{\bar{K}_{e}}{\bar{K}}=1+\left(\frac{1-\alpha}{\alpha}\right) \bar{Y}
$$

or

$$
\bar{K}=\frac{\bar{K}_{e}}{1+\left(\frac{1-\alpha}{\alpha}\right) \bar{Y}}
$$

where $\bar{Y}$ is the fractional occupancy $\left(\frac{B}{R_{o}}\right)$ and $\alpha$ is an interaction factor which is equal to $\bar{K}_{f} / \bar{K}_{e}$. By substituting $\bar{K}$ for the affinity constant in the classical Scatchard equation, we obtain

$$
\frac{B}{F}=\frac{\bar{K}_{e}}{1+\left(\frac{1-\alpha}{\alpha}\right) \bar{Y}}\left(R_{o}-B\right)
$$

or

$$
\frac{B}{F}=\frac{\tilde{K}_{e}}{1-\left(\frac{1-\alpha}{\alpha}\right)\left(\frac{B}{R_{o}}\right)}\left(R_{o}-B\right)
$$

The Scatchard plot is then a curve governed by three constants, $\bar{K}_{e}, R_{o}$, and $\alpha$, which are unknowns, and $B$ an $F$ which are the experimentally determined variables.
In this study, the Scatchard plots were determined using a PDP-10 computer with an M-Lab model-fitting program and a cooperative model designed by Pierre De Meyts for the insulin-receptor interaction. ${ }^{2}$ This program was designed to obtain the best fit of the data by varying $\bar{K}_{e}, \alpha$, and $R_{o}$ (the total receptor concentration). Analysis using this model consistently yielded a better fit of the data than a simple linear Scatchard plot. To minimize the influence of interassay variability, all data obtained on cells treated with antireceptor sera were compared with data on cells treated with the same concentration of normal sera studied in the same experiment.

\section{RESULTS}

Effects of serum on insulin binding. When isolated rat adipocytes were exposed to serum from the three patients with the Type $B$ form of insulin resistance and acanthosis nigricans (B-1, B-2, and B-3) at dilutions of $1: 20$ and then washed extensively to eliminate any free residual serum, there was a $30-95 \%$ decrease in subsequent insulin binding to these cells (Fig. 1, bottom). These correspond to the same three sera that exhibited anti-insulin receptor activity against human lymphocytes and monocytes $(2,3)$, and in fact, these sera show the same order of potency in rat adipose as in the human-derived tissues. Sera from the three patients with the Type A form of insulin resistance and acanthosis nigricans in whom there was no evidence for antireceptor activity in other systems, as well as sera from four patients with partial lipodystrophies and lipoatrophy, did not cause a significant decrease in insulin binding to these cells, despite clinical similarities among these patients and despite similar elevations of endogenous insulin. [ $\left.{ }^{125} \mathrm{I}\right]$ Insulin binding was also not affected by pretreatment of cells with normal serum, and ranged between 80 and $115 \%$ of the binding observed if the cells were exposed only to a buffer control (Fig. 1, bottom). In all of these experiments, nonspecific binding averaged $10-15 \%$ of the total binding and was not affected by serum pretreatment.

The inhibitory effect of the serum from the Type B patients on insulin binding was related to the concentration of serum used and to the patient from whom the serum was obtained (Fig. 2, dashed lines). Serum B-2 produced almost a complete inhibition of binding at a concentration of $1: 1,000$, and $50 \%$ inhibition at dilutions between 1:2,500 and 1:7,500; sera B-1 and B-3 were much less potent, producing $50 \%$ inhibition at dilutions of about $1: 5$ and $1: 20$, respectively.

As in our previous studies using cultured human lymphocytes (3), the inhibitor of insulin binding to isolated adipocytes was retained in the purified IgG fraction obtained from serum by DEAE chromatography

${ }^{2}$ The exact method of data analysis is being submitted elsewhere for publication. Details, however, may be obtained by writing to Dr. C. R. Kahn or P. De Meyts, Diabetes Branch, National Institutes of Health, Bethesda, Md. 20014. 

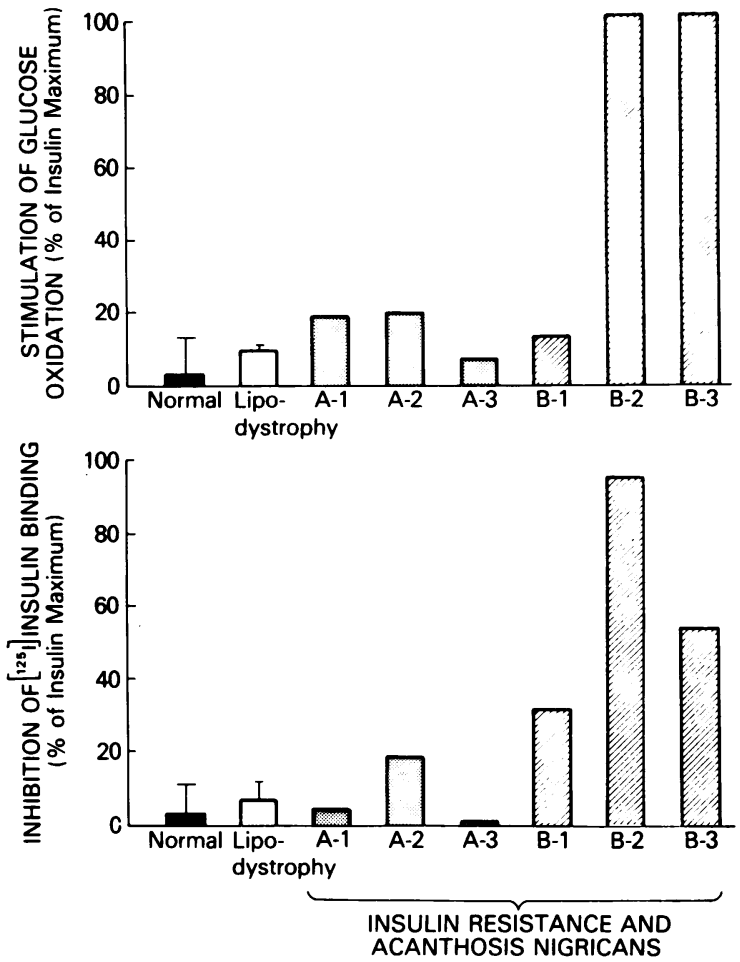

FIGURE 1 Effect of serum preincubation on insulin binding and glucose oxidation by isolated adipocytes. Isolated rat adipocytes were incubated for $15 \mathrm{~min}$ at $30^{\circ} \mathrm{C}$ with buffer, or a 1:20 dilution of normal serum $(n=7)$, serum from patients with lipodystrophy $(n=4)$, or serum from patients with the syndromes of insulin resistance and acanthosis nigricans. The cells were then washed three times with buffer and utilized in either an insulin binding experiment (bottom) or glucose oxidation experiment (top), as described in Methods. The inhibitory effect of serum was calculated as percentage inhibition produced by serum pretreatment versus that produced by $1 \mu \mathrm{M}$ insulin. In the glucose oxidation experiments, the effect of serum preincubation was expressed as the Percent stimulation above basal produced by serum pretreatment/ Percent stimulation above basal produced by insulin (7.5 $\mathrm{ng} / \mathrm{ml}) \times 100$. Insulin-stimulated glucose oxidation varied between four- and twelvefold the basal level in different experiments. All effects of the sera were studied in triplicate; the standard error of the mean is given only for those bars which represent the mean of several different sera.

(Fig. 3). Significant inhibition of insulin binding was observed after pretreatment with a concentration of IgG from patient B-2 as low as $5 \mu \mathrm{g} / \mathrm{ml}$. When this IgG fraction was subjected to pepsin digestion, the activity was found to reside in the isolated $F\left(a b^{\prime}\right)_{2}$ fragment. Thus the inhibitor of insulin binding to adipocytes which is present in these sera appears to be cell-directed antibody which binds by the $\mathrm{F}\left(\mathrm{ab}^{\prime}\right)_{2}$ region of the molecule.

Mechanism of the inhibition of insulin binding. To determine the nature of this inhibitory effect, the concentration dependence of $\left.{ }^{[125} \mathrm{I}\right]$ insulin binding to adi-

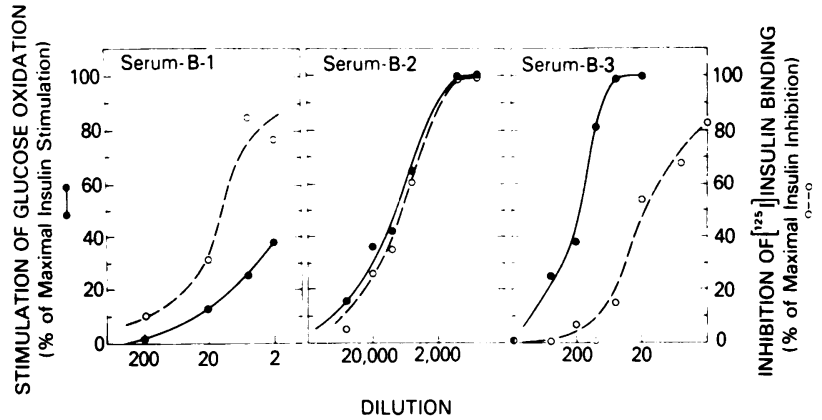

Figure 2 Comparison of effects of serum preincubation on insulin binding and glucose oxidation by isolated adipocytes. Adipocytes were exposed to the indicated dilution of sera B-1, B-2, or B-3 and to similar dilutions of control serum. The effect of serum preincubation on insulin binding $(\mathrm{O}-\mathrm{O})$ and glucose oxidation (- - was then assessed as described in the legend to Fig. 1.

pocytes was studied using cells that had been pretreated with normal or antibody-containing sera (Fig. $4 \mathrm{~A})$. In each case the inhibition of binding produced by the antireceptor serum was greatest at low concentrations of insulin and decreased with increasing insulin concentration, suggesting a competitive type of inhibition.

As with other insulin receptors, Scatchard analysis of insulin binding to isolated adipocytes yielded curvi-

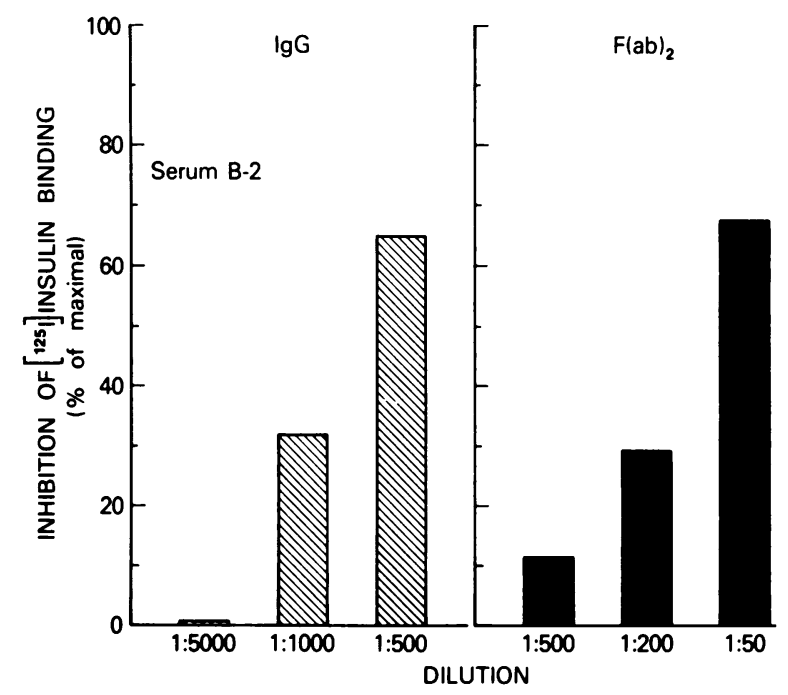

Figure 3 Effect of IgG and $F\left(a b^{\prime}\right)_{2}$ on insulin binding to adipocytes. A purified fraction of IgG was obtained from serum B-2 by DEAE chromatography and the $F\left(a b^{\prime}\right)_{2}$ was prepared by pepsin digestion. Adipocytes were then pretreated with the indicated dilutions of these preparations and insulin binding determined as indicated in the legend to Fig. 1. The concentration of the IgG preparation was about $8 \mathrm{mg} / \mathrm{ml}$. The exact concentration of the $F\left(a b^{\prime}\right)_{2}$ in these experiments is uncertain since carrier IgG was added during the pepsin treatment and subsequent gel filtration. Based on other experiments, however, it is probably about $1 \mathrm{mg} / \mathrm{ml}$. 

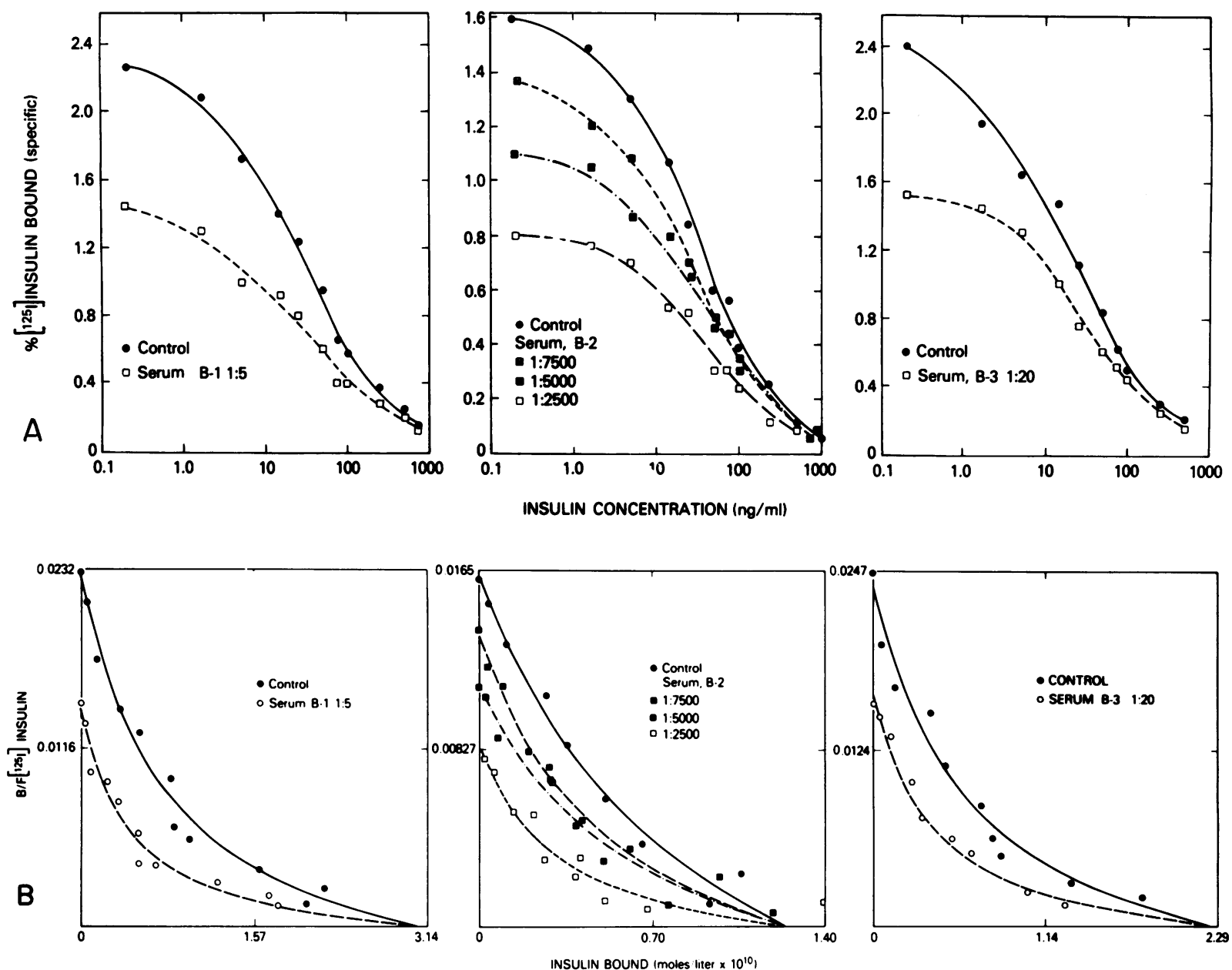

FIGURE 4 (A) Effect of anti-insulin receptor antisera on insulin binding to adipocytes. Adipocytes were preincubated with control serum or antireceptor sera B-1, B-2, and B-3 at the indicated dilutions then used in a binding assay as described in Fig. 1. In some incubation tubes, unlabeled insulin was added at the indicated concentrations. The percent [ $\left.{ }^{125} \mathrm{I}\right]$ insulin bound is plotted as a function of total insulin concentration. Nonspecific binding has been subtracted. Each panel represents a separate experiment and data on the antibody-treated cells are compared with the control for that experiment each done in triplicate. (B) Scatchard plot of the above data. The points represent experimental data. The curves were determined using the cooperative model and the constrained fit with receptor concentrations fixed (see Methods).

linear plots (see Methods) (Fig. 4 B). The best fitting curve and the values for $R_{o}$ (receptor concentration), $\bar{K}_{e}$ (the affinity of the high affinity state or empty receptor), and the interaction factor $\alpha$ (the ratio of $\bar{K}_{f}$ to $\bar{K}_{e}$ ) were determined using a modeling program as discussed in Methods (Table I). The average $\bar{K}_{e}$ for the adipocytes treated with buffer or normal serum was $1.03 \pm 0.17 \times 10^{8} \mathrm{liters} / \mathrm{mol}$. There was a trend to observe lower values of $\bar{K}_{e}$ in cells treated with higher concentrations of normal serum; however, this was not statistically significant due to the interassay variability observed with adipocytes. The average interaction factor $(\alpha)$ was $0.28 \pm 0.06$ for the control cells and the calculated mean $\bar{K}_{f}$ was $0.31 \pm 0.11 \times 10^{8}$ liters $/ \mathrm{mol}$.
Scatchard analysis of cells pretreated with all three antireceptor sera revealed that the decrease in insulin binding could be accounted for by a decrease in $\bar{K}_{e}$ (Table I, Fig. 4 B). Cells treated with serum B-2 showed a concentration-dependent decrease in insulin binding and in $\bar{K}_{e}$ with no systematic change in $R_{o}$ (Table I). With the other two sera, the computer-fit Scatchard analysis suggested a slight increase in $R_{o}$ on the antibodytreated cells; due to the large error in the estimate of $R_{o}$, however, these were not statistically significant. This analysis, then, suggests that the entire decrease in binding observed after serum treatment can be accounted for by a decrease in receptor affinity only, consistent with the notion that the antireceptor antibodies 
TABLE I

Equilibrium Constants* for Insulin Binding to Adipocytes Pretreated with Antireceptor Antibodies

\begin{tabular}{cllccc}
\hline $\begin{array}{c}\text { Experi- } \\
\text { ment }\end{array}$ & Serum & Dilution & $\begin{array}{c}\text { Receptor } \\
\text { affinity, } \\
\bar{K}_{e}\end{array}$ & $\begin{array}{c}\text { Receptor } \\
\text { concentration, } \\
R_{o}\end{array}$ & $\begin{array}{c}\text { Interaction } \\
\text { factor, } \\
\alpha\end{array}$ \\
\hline & & & $10^{8}$ liters/mol & nmol/liter & \\
I & Control & $1: 5$ & $0.74 \pm 0.15$ & $0.314 \pm 0.066$ & $0.20 \pm 0.07$ \\
& B-1 & $1: 5$ & $0.35 \pm 0.24$ & $0.411 \pm 0.281$ & $0.09 \pm 0.08$ \\
II & Control & $1: 2,500$ & $1.32 \pm 0.18$ & $0.126 \pm 0.018$ & $0.41 \pm 0.14$ \\
& B-2 & $1: 7,500$ & $0.97 \pm 0.12$ & $0.143 \pm 0.019$ & $0.25 \pm 0.05$ \\
& & $1: 5,000$ & $0.98 \pm 0.21$ & $0.115 \pm 0.027$ & $0.41 \pm 0.20$ \\
& & $1: 2,500$ & $0.50 \pm 0.28$ & $0.172 \pm 0.088$ & $0.14 \pm 0.11$ \\
III & Control & $1: 20$ & $1.03 \pm 0.29$ & $0.229 \pm 0.063$ & $0.23 \pm 0.11$ \\
& B-3 & $1: 20$ & $0.49 \pm 0.61$ & $0.342 \pm 0.222$ & $0.09 \pm 0.15$ \\
& & & &
\end{tabular}

* The equilibrium constants presented here are those obtained using a cooperative model of hormone binding and an unconstrained computer fit. For details of the method used to obtain these values, see the text. All data are expressed as the mean $\pm \mathrm{SD}$.

act as competitive inhibitors on insulin binding in these cells. A similar conclusion was reached by computerfitting the data by using a constrained curvilinear model or a simple linear regression analysis. Studies at $15^{\circ} \mathrm{C}$ using cultured human lymphocytes reveal that these same sera have somewhat different effects on insulin binding including changes in association rate, dissociation rate, negative cooperativity, and available receptor number (12). Because of experimental limitations or perhaps differences in the mechanism of antibody action, these cannot be distinguished in the binding studies in adipocytes at $37^{\circ} \mathrm{C}$.

Effects of antireceptor sera on basal glucose oxidation. Preincubation of adipocytes with sera from patients with Type B insulin resistance and acanthosis nigricans also results in altered glucose oxidation (Fig. 1, top). Preincubation with 1:20 dilutions of serum from patients B-2 and B-3, who had evidence for antireceptor antibodies as measured by inhibition of $\left.{ }^{125} \mathrm{I}\right]$ insulin binding, stimulated glucose oxidation dramatically. This effect on glucose oxidation was linear over the entire 2-h incubation despite the fact that the cells had only been exposed to serum for $15 \mathrm{~min}$ at $30^{\circ} \mathrm{C}$ and washed before the study (data not shown). In contrast, basal glucose oxidation was not altered in cells which had been preincubated with 1:20 dilutions of sera from patients A-1, A-2, or A-3, who have high endogenous insulin levels (100-300 $\mu \mathrm{U} / \mathrm{ml})$ but no antireceptor activity. Serum from four patients with partial or complete lipodystrophy, normal serum, or normal serum to which $10 \mathrm{ng} / \mathrm{ml}(250 \mu \mathrm{U} / \mathrm{ml})$ of porcine insulin was added showed little or no effect on basal glucose oxidation under the same experimental design, i.e., present only during a $15-\mathrm{min}$ preincubation at a 1:20 dilution.

The effects of the three antireceptor sera on basal glucose oxidation are shown in more detail in Fig. 2 (solid lines). Note that whereas high concentration of all three sera could produce $80-95 \%$ inhibition of insulin binding, their effects on glucose oxidation were variable. Serum B-1 produced only a $40 \%$ stimulation of glucose oxidation, even at 1:2 dilution. In contrast, sera B-2 and B-3 could produce stimulation of glucose oxidation equivalent to that produced by maximal concentrations of insulin at dilutions of 1:2,000 and 1:100 in the preincubation.

The insulin-like effects of the antireceptor antisera were also apparent when other biological responses were measured (Table II). Serum B-2, which had the highest titer of antireceptor activity, produced maximal or near-maximal stimulation of 2-deoxy-glucose transport, glucose incorporation into lipid, and glucose incorporation into glycogen at dilutions of 1:5,000 and $1: 1,000$, whereas normal serum had little or no effect at dilutions of 1:500.

\section{TABLE II}

Effect of Serum B-2 on Glucose Incorporation into Lipid and Glycogen and 2-Deoxy-Glucose Transport

\begin{tabular}{|c|c|c|c|}
\hline \multirow[b]{2}{*}{ Additions } & \multicolumn{2}{|c|}{$\begin{array}{c}\text { Incorporation of } \\
{\left[\mathrm{U}-{ }^{14} \mathrm{C}\right] \text { glucose into }}\end{array}$} & \multirow{2}{*}{$\begin{array}{l}\text { 2-Deoxy-glucose } \\
\text { transport }\end{array}$} \\
\hline & Glycogen* & Lipid* & \\
\hline & $\begin{array}{l}\mu \mathrm{mol} / \mathrm{liter} \\
\text { per } 20 \mathrm{~min}\end{array}$ & 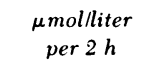 & $\begin{array}{l}\text { Mmol/liter } \\
\text { per } 2 \text { min }\end{array}$ \\
\hline None & $2.75 \pm 0.01$ & $47.3 \pm 1.5$ & 0.40 \\
\hline $\begin{array}{l}\text { Insulin } \\
0.25 \mathrm{ng} / \mathrm{ml} \\
1.0 \mathrm{ng} / \mathrm{ml} \\
1.5 \mathrm{ng} / \mathrm{ml} \\
10.0 \mathrm{ng} / \mathrm{ml}\end{array}$ & $\begin{array}{c}5.45 \pm 0.01 \\
8.25 \pm 0.01 \\
- \\
8.50 \pm 0.02\end{array}$ & $\begin{array}{c}88.8 \pm 0.8 \\
146.2 \pm 12.7 \\
- \\
199.2 \pm 0.8\end{array}$ & $\begin{array}{c}1.70 \pm 0.1 \\
- \\
1.95 \pm 0.3 \\
-\end{array}$ \\
\hline $\begin{array}{c}\text { Serum B-2 } \\
1: 10,000 \\
1: 5,000 \\
1: 1,000 \\
1: 500\end{array}$ & $\begin{array}{l}5.15 \pm 0.02 \\
6.65 \pm 0.02 \\
8.20 \pm 0.02 \\
8.50 \pm 0.03\end{array}$ & $\begin{array}{l}172.8 \pm 5.7 \\
195.8 \pm 4.1 \\
205.7 \pm 0.4 \\
209.4 \pm 4.4\end{array}$ & $\begin{array}{c}1.85 \pm 0.01 \\
- \\
2.35 \pm 0.20 \\
2.20 \pm 0.20\end{array}$ \\
\hline $\begin{array}{l}\text { Normal serum } \\
1: 500\end{array}$ & $3.65 \pm 0.01$ & $67.4 \pm 0.1$ & $0.75 \pm 0.01$ \\
\hline
\end{tabular}

* [U- $\left.{ }^{14} \mathrm{C}\right]$ glucose incorporation into glycogen and lipid was measured as described in Methods. The total glucose concentration for these experiments was $3.0 \mathrm{mmol} / \mathrm{liter}$, and the data are expressed as micromoles per liter incorporated during the appropriate incubation periods. An assay blank was determined for the glycogen synthesis as described by Lawrence et al. (8). An assay blank was determined for the lipid synthesis by keeping one set of tubes at $4^{\circ} \mathrm{C}$ for $2 \mathrm{~h}$ and then extracting the lipids. Both blanks were subtracted from the total counts before calculating the actual incorporation.

$\$$ 2-Deoxy-glucose transport was determined as described in Methods, using a 2-deoxy-glucose concentration of 0.25 $\mathrm{mmol} /$ liter. The extracellular water space was determined by $\left[{ }^{14} \mathrm{C}-\right.$ ]inulin and has been subtracted from the results. 
The stimulatory or insulin-like effect observed with these sera was due to the antireceptor immunoglobulins, not insulin. Addition of antihuman IgG to the preincubation with the most potent serum (B-2) resulted in an inhibition of most of the insulin-like effect (Fig. 5). In contrast, anti-insulin serum, in a concentration sufficient to inhibit insulin-stimulated glucose oxidation, had no effect on the stimulation produced by the antireceptor sera.

The stimulatory effect was also retained in partially purified immunoglobulin fractions. IgG fractions from both B-2 and B-3 purified by ionic exchange or gel filtration chromatography showed a five- to ten-fold enrichment in insulin-like activity when compared with whole serum (Fig. $6 \mathrm{~A}$ and $6 \mathrm{~B}$ ). IgG from serum B-2 produced significant stimulation of glucose oxidation at concentrations as low as $0.2 \mu \mathrm{g} / \mathrm{ml}$, and stimulation was maximal by concentrations of $10 \mu \mathrm{g} / \mathrm{ml}$. The stimulatory activity was also retained in the $\mathrm{F}\left(\mathrm{ab}^{\prime}\right)_{2}$ fragments of this IgG (Fig. $6 \mathrm{~A}$ ). Insulin-like activity was also observed with IgM-containing fractions from serum B-3 (Fig. $6 \mathrm{~B}$, a finding which correlates well with the fact that inhibitory activity is also associated with IgM of this serum (3).

Effects of antireceptor serum on insulin-stimulated glucose oxidation. Only one of the three sera could be shown to inhibit insulin-stimulated glucose oxidation. When the cells preincubated with 1:2 dilution of serum B-1 were subjected to further stimulation by insulin, the dose response of glucose oxidation was clearly shifted to the right (Fig. 7). The dose of insulin producing half-maximal stimulation of the antibodytreated cells was $1.5 \mathrm{ng} / \mathrm{ml}$ as compared with about $0.3 \mathrm{ng} / \mathrm{ml}$ for cells pretreated with normal sera. This fivefold shift in insulin sensitivity correlates well with the concomitant $80 \%$ reduction in insulin binding observed with these cells (Fig. 2). In contrast, preincubation of adipocytes with serum B-1 did not inhibit spermine-stimulated glucose oxidation (Table III).

No inhibition of insulin-stimulated glucose oxidation could be demonstrated with serum B-2 or B-3, since they had such potent stimulatory effects themselves. The stimulatory effects of sera B-2 and B-3 were further augmented by insulin when both were present at sub-

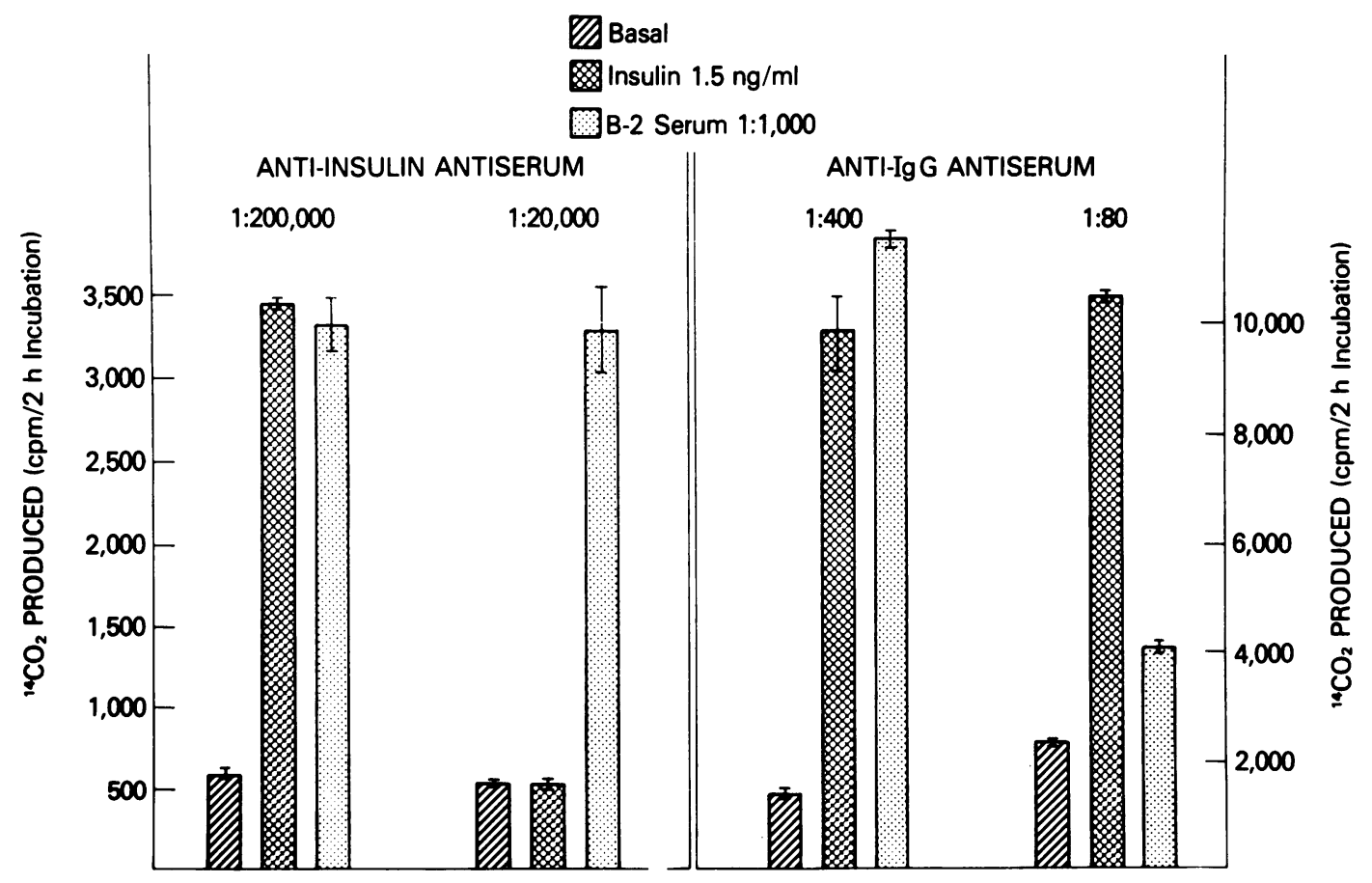

FIGURE 5 Inhibition of serum effect by antihuman IgG. Duplicate sets of incubation flasks containing $1 \mathrm{ml}$ of $\mathrm{KRB}-\mathrm{A}$ with $\left[{ }^{14} \mathrm{C}\right]$ glucose were prepared. In each set there were three flasks with buffer only, and three each to which insulin $(1.5 \mathrm{ng} / \mathrm{ml})$ or serum B-2 (1:1,000 dilution) has been added. In the experiment shown at the left, anti-insulin serum was added to each set of flasks at the indicated dilutions. In the experiment shown at the right, antihuman IgG was added to each set of flasks at the indicated dilution. The flasks were allowed to incubate for $15 \mathrm{~min}$ at $22^{\circ} \mathrm{C}$ after which adipocytes were added and the flasks were gassed and capped. The flasks were then incubated for $2 \mathrm{~h}$ at $37^{\circ} \mathrm{C}$ and the ${ }^{14} \mathrm{CO}_{2}$ evolved collected in hyamine hydroxide as described in Methods. 

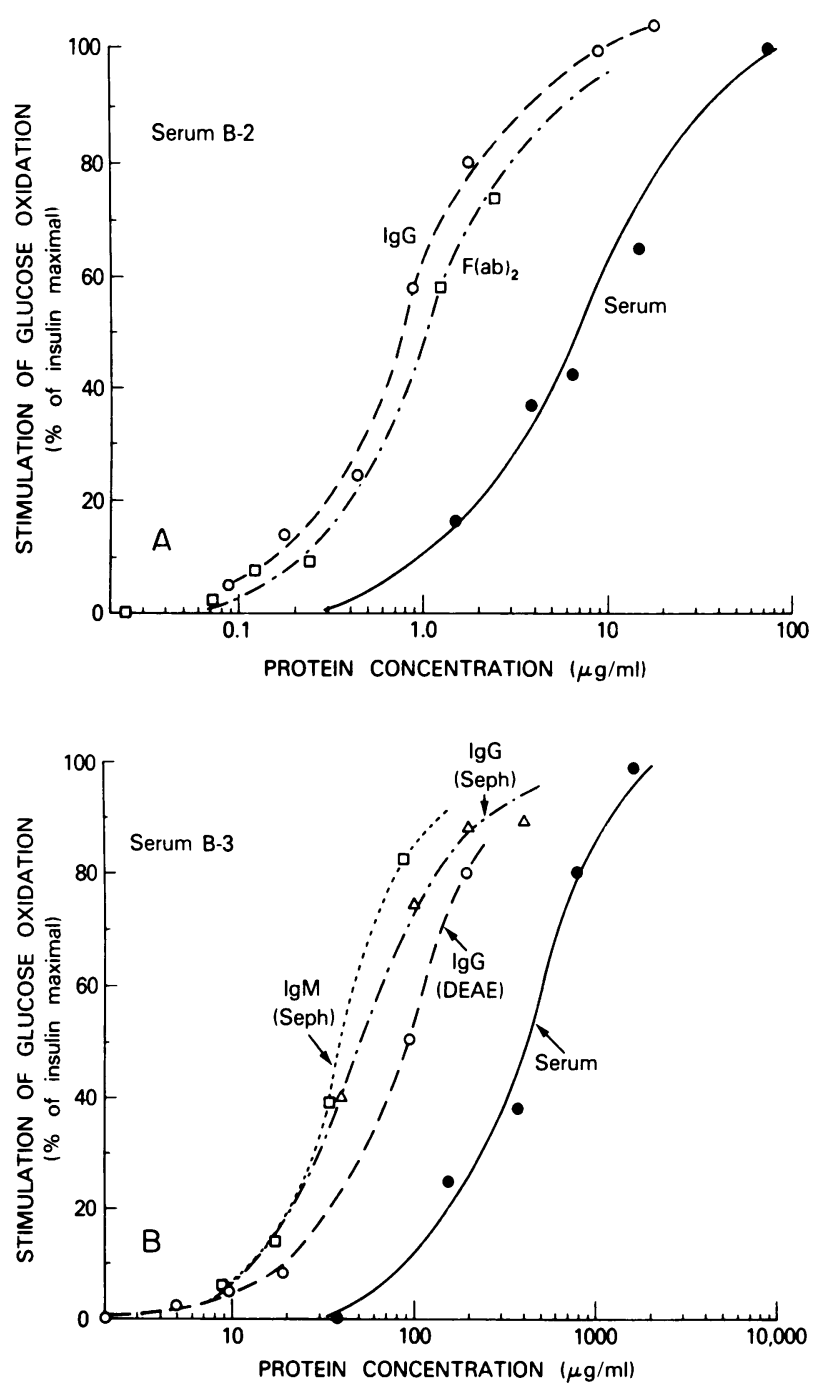

FIGURE 6 Effect of purified immunoglobulin fractions on glucose oxidation. (A) IgG and $\mathrm{F}\left(\mathrm{ab}^{\prime}\right)_{2}$ fractions were prepared from serum B-2 by DEAE chromatography and pepsin digestion. The effects of these fractions and the whole serum on glucose oxidation were performed as described in Methods. (B) IgG-enriched fractions of serum B-3 were prepared by gel filtration on Sephadex G-200 or DEAE chromatography and an IgM-enriched fraction by gel filtration on Sephadex G-200. The effects of these fractions and the whole serum on glucose oxidation were performed as described in Methods.

maximal concentrations (Table IV). At maximally effective concentrations, the stimulatory effects of the antireceptor sera and insulin were similar in magnitude, and there was no increase in glucose oxidation when both were used together.

Mechanism of the antibody effects on glucose oxidation. The insulin-like activity produced by the antireceptor sera appears to be due to an interaction of the antibody with the receptor in a manner distinct from

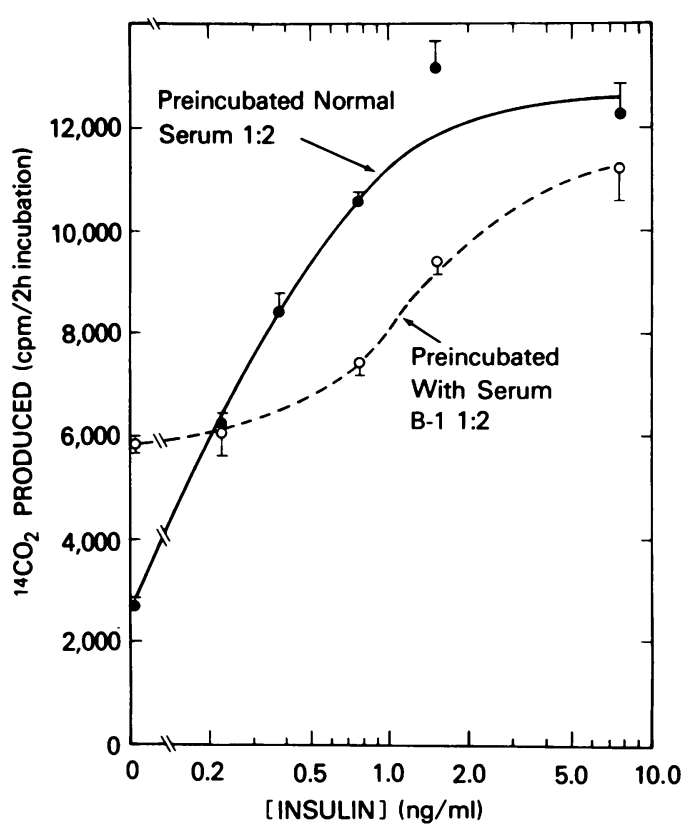

Figure 7 Effect of serum B-1 on glucose oxidation by isolated adipocytes. Cells were preincubated with a 1:2 dilution of serum B-1 or normal control serum. The cells were then washed and used in a glucose oxidation bioassay as described in the legend to Fig. 1 and Methods. Some flasks also contained insulin at the indicated concentrations during the bioassay.

that which results in the inhibition of insulin binding. This is suggested both by a careful quantitative comparison of the effects of serum on binding and bioactivity and by the qualitative differences observed after enzymatic treatment of the adipocytes. For example, serum B-1 inhibited insulin binding much more effec-

TABLE III

Effect of Serum B-1 on Spermine-Stimulated Glucose Oxidation by Adipocytes*

\begin{tabular}{clc}
\hline & \multicolumn{2}{c}{ Preincubation with } \\
\cline { 2 - 3 } Spermine concentrate & \multicolumn{1}{c}{$\begin{array}{c}\text { Control serum } \\
(1: 2)\end{array}$} & $\begin{array}{c}\text { Serum B-1 } \\
(1: 2)\end{array}$ \\
\hline$\mu$ mollhiter & \multicolumn{2}{c}{$c p m{ }^{14} \mathrm{CO}_{2}$ evolved $/ 2 h$} \\
0 & $1,121 \pm 65$ & $2,439 \pm 203$ \\
0.3 & $1,966 \pm 104$ & $3,372 \pm 45$ \\
1.5 & $3,554 \pm 76$ & $4,031 \pm 170$ \\
3.0 & $3,988 \pm$ & $3,975 \pm 154$ \\
5.0 & $4,075 \pm 19$ & $3,802 \pm 82$ \\
\hline
\end{tabular}

* Cells were preincubated with a 1:2 dilution of normal serum or antireceptor serum as described in Methods. Cells were then used in a glucose oxidation experiment. Incubation was for $2 \mathrm{~h}$ at $37^{\circ} \mathrm{C}$, and the ${ }^{{ }^{44}} \mathrm{CO}_{2}$ evolved was collected as described in Methods. 
TABLE IV

Effects of Insulin on Glucose Oxidation by Adipocytes Pretreated with Antireceptor Sera B-2 and B-3

\begin{tabular}{|c|c|c|c|c|}
\hline \multirow[b]{2}{*}{$\begin{array}{c}\text { Insulin } \\
\text { concentration }\end{array}$} & \multicolumn{2}{|c|}{ Experiment I, preincubation with } & \multicolumn{2}{|c|}{ Experiment II, preincubation with } \\
\hline & $\begin{array}{c}\text { Control serum } \\
(1: 10,000)\end{array}$ & $\begin{array}{l}\text { Serum B-2 } \\
(1: 10,000)\end{array}$ & $\begin{array}{c}\text { Control serum } \\
(1: 10,000)\end{array}$ & $\begin{array}{l}\text { Serum B-2 } \\
(1: 10,000)\end{array}$ \\
\hline$n g / m l$ & \multicolumn{2}{|c|}{$c p m{ }^{14} \mathrm{CO}_{2}$ evolved $/ 2 \mathrm{~h}$} & \multicolumn{2}{|c|}{$\mathrm{cpm}{ }^{14} \mathrm{CO}_{2}$ evolved $/ 2 \mathrm{~h}$} \\
\hline 0 & $1,522 \pm 81$ & $3,118 \pm 164$ & $2,018 \pm 77$ & $5,126 \pm 162$ \\
\hline 0.225 & $2,600 \pm 31$ & $4,721 \pm 151$ & $4,742 \pm 35$ & $8,022 \pm 343$ \\
\hline 0.375 & $3,541 \pm 137$ & $4,845 \pm 424$ & $6,686 \pm 161$ & $9,523 \pm 220$ \\
\hline 0.750 & $4,954 \pm 112$ & $5,408 \pm 243$ & $8,906 \pm 243$ & $10,448 \pm 142$ \\
\hline 1.5 & $7,426 \pm 26$ & $6,663 \pm 253$ & $11,642 \pm 127$ & $12,755 \pm 128$ \\
\hline \multirow[t]{2}{*}{7.5} & $7,117 \pm 87$ & $6,730 \pm 443$ & $12,397 \pm 25$ & $13,174 \pm 324$ \\
\hline & \multicolumn{4}{|c|}{ Experiment III, preincubation with } \\
\hline \multirow[t]{2}{*}{$\begin{array}{c}\text { Insulin } \\
\text { concentration }\end{array}$} & $\begin{array}{c}\text { Control serum } \\
(1: 20)\end{array}$ & $\begin{array}{c}\text { Serum B-3 } \\
(1: 2,000)\end{array}$ & $\begin{array}{c}\text { Serum B-3 } \\
(1: 200)\end{array}$ & $\begin{array}{c}\text { Serum B-3 } \\
(1: 20)\end{array}$ \\
\hline & \multicolumn{4}{|c|}{ cpm ${ }^{14} \mathrm{CO}_{2}$ evolved $/ 2 \mathrm{~h}$} \\
\hline 0 & $3,240 \pm 190$ & $2,988 \pm 230$ & $6,883 \pm 407$ & $14,555 \pm 1,835$ \\
\hline 0.375 & $8,651 \pm 440$ & $9,056 \pm 386$ & $11,046 \pm 374$ & $13,869 \pm 476$ \\
\hline 1.5 & $13,389 \pm 830$ & $15,783 \pm 476$ & $16,074 \pm 767$ & $13,782 \pm 1,439$ \\
\hline 7.5 & $14,724 \pm 531$ & $15,232 \pm 826$ & $14,861 \pm 957$ & $13,566 \pm 1,211$ \\
\hline
\end{tabular}

* Cells were preincubated with the indicated concentrations of control or antireceptor serum as described in Methods. Cells were then used in a glucose oxidation experiment. In some incubation flasks, insulin was added at the indicated concentrations. Incubation was for $2 \mathrm{~h}$ at $37^{\circ} \mathrm{C}$, and the ${ }^{14} \mathrm{CO}_{2}$ evolved collected as described in Methods.

tively than it stimulated glucose oxidation, whereas serum B-3 stimulated glucose oxidation more effectively than it inhibited binding (Fig. 2). With serum B-2, the curves for stimulation of glucose oxidation and inhibition of insulin binding were almost superimposable. Note that insulin itself causes a maximal stimulation of glucose oxidation while inhibiting insulin binding by only $5 \%$, a finding which is consistent with the presence of spare receptors $(7,9,21)$. Serum B-3 has a curve similar to that of insulin and produces maximal stimulation of glucose oxidation at a time when insulin binding is inhibited by only about $15 \%$. In contrast, serum B-2 shows almost a linear relationship between binding-inhibition and stimulation of glucose oxidation, and serum B-1 has less effect on glucose oxidation than on insulin binding. Compared with insulin or serum B-3, sera B-1 and B-2 are behaving as partial agonists toward the insulin receptor. Further study is required to learn whether this is due to differences in the intrinsic activity of the antibodies in the different sera or simply due to heterogeneity in the populations of antibodies.

Effects of antibody on enzymatically treated cells. The possibility that these antisera were binding to separate regions of the insulin receptor was explored in more detail using cells which had been enzymatically treated. When cells were digested with neuraminidase $(5 \mu \mathrm{g} / \mathrm{ml})$, basal, insulin-stimulated, and antibody-stimulated glucose oxidation decreased in parallel (data not shown). Glucose oxidation stimulated by concanavalin A and spermine also decreased (data not shown). This suggests that neuraminidase acts directly to damage the glucose transport mechanism or some other factor common to the glucose oxidation which is observed under all of these circumstances (22).

In contrast, when fat cells were digested with varying concentrations of trypsin, there was a greater loss of insulin-stimulated glucose oxidation than of glucose oxidation stimulated by the antireceptor sera (Fig. 8). This difference was most marked with sera B-1 and B-2. Of the sera, the stimulatory effect of B-3 was the most sensitive to trypsin and most closely resembled the results obtained with insulin-stimulated glucose oxidation.

\section{DISCUSSION}

Antibodies that bind to cell membranes and alter receptor function have now been described in three disease syndromes: Graves' disease $(23,24)$, myasthenia gravis 


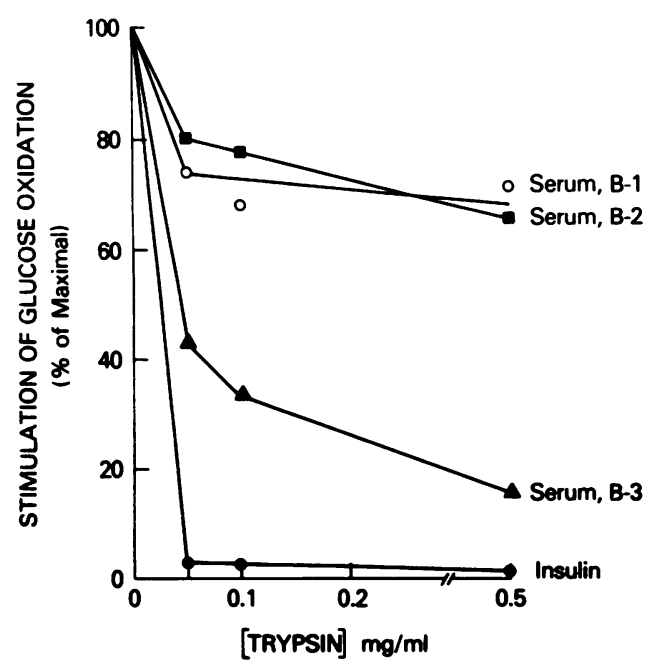

FIGURE 8 Effect of trypsin on glucose oxidation. Adipocytes were incubated with either buffer or trypsin (at the indicated concentrations) for $15 \mathrm{~min}$ at $37^{\circ} \mathrm{C}$. Trypsin inhibitor was then added, and the cells were washed two times and then aliquoted for use in a glucose oxidation assay as described in Methods. In this experiment, insulin and the sera at the indicated concentrations were present during the entire glucose oxidation assay.

(25-28), and the Type B form of insulin resistance associated with acanthosis nigricans (1-3). We have previously shown that the sera of patients with the latter syndrome contain antibodies which block insulin binding to receptors in several tissues including human lymphocytes and monocytes and rat hepatocytes. In the present study, we have used these antibodies as a probe of the insulin receptor in isolated rat adipocytes.

As in our previous studies, all three sera containing antireceptor antibodies inhibited insulin binding to the isolated adipocytes. The inhibitory titers in these experiments ranged from $1: 7,500$ to $1: 5$ for these three sera and were very close to those observed with human cells $(2,3)$, suggesting a high degree of similarity between the insulin receptor of the rat adipocyte and those on human white blood cells. All three sera produced this decrease in insulin binding by decreasing the affinity of the receptor for insulin. This is in contrast to what we have observed in similar experiments using cultured human lymphocytes, where at least one serum blocks insulin binding by decreasing available receptor number (12). Whether this represents an intrinsic difference in the adipocyte and lymphocyte receptors or reflects differences in experimental conditions such as time, temperature, and buffer composition is uncertain.

In the isolated adipocyte, these antireceptor sera also had profound effects on glucose utilization. Serum B-1, which had minimal effects on basal glucose oxidation, inhibited insulin-stimulated glucose oxidation in direct proportion to its ability to inhibit insulin binding. Thus, treatment of cells with a concentration of serum which inhibited binding by $80 \%$ caused a fivefold shift to the right in the dose response curve of insulin-stimulated (but not spermine-stimulated) glucose oxidation. Since only about 5-10\% of all receptors need to be occupied to produce maximal stimulation of glucose oxidation, this serum pretreatment does not alter insulin's ability to produce this maximal response.

The other two sera are especially interesting since they had considerable ability to stimulate glucose utilization, suggesting perhaps that they bind even closer to the site on the receptor responsible for induction of this biological effect. Serum B-3, like insulin, demonstrated a maximal stimulation of glucose oxidation with a concentration which produced only $10 \%$ inhibition of $\left.{ }^{[25} \mathrm{I}\right]$ insulin binding, whereas serum B-2 produced almost superimposable curves for inhibition of insulin binding and stimulation of glucose oxidation. At maximally effective concentrations, the effects of insulin and antireceptor antibody were equal and not additive, while at submaximal concentrations insulin enhanced the stimulating activity of the antibody, suggesting that these two agents act through a common pathway in stimulating this response. Serum B-2, which contained the highest titers of antireceptor antibodies, also stimulated glucose incorporation into lipid and glycogen, as well as stimulated directly the uptake of 2 -deoxyglucose.

Both the inhibition of insulin binding and the insulin-like biological effects were due to the immunoglobulins in these sera. Both were retained in the partially purified IgG, and in one case IgM, fractions of serum. In addition, both activities were retained in the $F\left(a b^{\prime}\right)_{2}$ fragments obtained by pepsin digestion. Further, both the inhibitory activity (3) and the insulin-like biological effect of the serum were lost after preincubation of the serum with antihuman IgG, but not by treatment with anti-insulin antibodies. At present, however, it is impossible to exclude the possibility that the biological responses and inhibition of binding are due to different populations of antibody molecules contained in the serum or IgG preparation.

In an elegant study of one of the first patients with insulin resistance and acanthosis nigricans (it is difficult to decide if this patient was more like our Type A or Type B patients), Field and co-workers demonstrated a marked increase in the insulin-like activity of serum by bioassay (29). On fractionation of the serum by starchblock electrophoresis, this bioactivity appeared in the zone between $\gamma$ - and $\beta$-globulins. In this case, however, at least some of the activity appeared to be due to insulin bound to anti-insulin antibodies.

Data from a number of sources suggest that the antibodies that block insulin binding and stimulate glucose oxidation most likely act by binding directly to some 
component of the insulin receptor. Thus these anti-receptor antibodies block insulin binding in a wide variety of tissues from species as diverse as the North Atlantic hagfish and man $(2,3)$. This inhibition of insulin binding is specific. Insulin degradation (30), as well as binding of glucagon, epidermal growth factor, growth hormone, and NSILA-s (a circulating insulin-like peptide) to their specific receptors on these same target cells is unaffected (2). ${ }^{3}$ The antisera also block insulin binding to and precipitate the solubilized insulin receptor. ${ }^{4}$ Interestingly, these antisera fail to affect insulin binding to sites on intracellular organelles, such as endoplasmic reticulum and nuclei, suggesting that these are immunologically distinct from the plasma membrane binding sites. ${ }^{3}$ Using ${ }^{125}$ I-labeled immunoglobulins from patient B-2, we have recently demonstrated a component of the IgG which binds specifically to cells in direct proportion to the insulin receptor concentration and have shown directly that insulin and this IgG compete with each other for binding to the cell membrane (11). Obviously, ultimate proof that the antibody binds directly to the receptor awaits complete purification of this membrane protein.

The antibodies present in this sera appear to have different binding sites on or near the insulin receptor complex as judged by differences in their bioactivities on normal and trypsinized cells. The fact that trypsin altered the responsiveness of the cell to all three antibodies suggests that the cell membrane structure with which these antibodies reacts is protein, at least in part. Serum B-3 was most insulin-like in its bioactivity curve (Fig. 4) and similar to insulin in that its effect was markedly decreased on cells which had been trypsinized. These findings, plus the fact that serum B-3 blocks insulin receptors almost equally well in a wide variety of species, ${ }^{5}$ suggests that this serum contains a population of antibodies which bind close to the site on the receptor to which insulin binds and that this site has been well conserved in evolution. Even with serum B-3, however, it is clear that the antibody specificity is not exactly identical with that of insulin.

Although the insulin receptor is most likely a glycoprotein, at present we have no data to suggest that these antibodies are like the plant lectins which bind to diverse membrane glycoproteins and produce insulinlike biological effects (31-33). Thus, cells are not protected from the potent inhibitory effect of serum B-2 by prior addition of sugars which are known to inhibit the

${ }^{3}$ Goldfine, I. D., R. Vigneri, D. Cohen, N. B. Pliam, and C. R. Kahn. Evidence that intracellular insulin binding sites are immunologically distinct from those on the plasma membrane. Nature (Lond.). In press.

${ }^{4}$ Harrison, L., J. S. Flier, and C. R. Kahn. Unpublished observation.

${ }^{5}$ Muggeo, M., B. Ginsberg, C. R. Kahn, P. De Meyts, and J. Roth. Manuscript in preparation. binding of many lectins $(0.2 \mathrm{M} \mathrm{N}$-acetyl glucosamine, $\mathrm{N}$-acetyl galactosamine, D-galactose, L-fucose, or $\alpha$ methyl mannoside) or by addition of other glycoproteins $\left(25 \mathrm{mg} / \mathrm{ml}\right.$ fetuin, ovalbumin, or thyroglobulin). ${ }^{6}$ Pretreatment of cells with neuraminidase did decrease the insulin-like effects of the antireceptor sera, but this appeared to be by acting at some step beyond the receptor, since both basal and all forms of stimulated glucose oxidation were equally affected.

On the other hand, the fact that the antireceptor antibodies and the plant lectins are multivalent may be of some interest in determining the mechanism of action of these substances. Succinylated concanvallin A, which cannot induce patch and cap formation, retains its insulin-like effects, albeit at a reduced potency. ${ }^{7}$ Similarly, preliminary experiments suggest that the

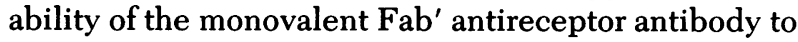
stimulate glucose oxidation is reduced. ${ }^{7}$ Both of these findings may be important clues in the mechanism of action of these substances, and perhaps of insulin, or may simply be consistent with the decrease in affinity which occurs when the number of binding sites on multivalent ligands is decreased (34). This problem is currently under study.

These effects of the anti-insulin receptor antibodies in vitro only partially reflect the presumed effect of these same antibodies in vivo. Clearly, circulating monocytes derived from the patients with these antibodies show an alteration in insulin binding similar to that produced in vitro in isolated adipocytes. In contrast, however, all three of the patients whose sera were used in this study had symptoms early in the course of their disease primarily related to insulin resistance and hyperglycemia, suggesting that the insulin-like effect observed in vitro is not maintained in vivo. This could reflect differences in chronic versus acute exposure, or differences in effects on adipocytes versus other tissues more important for glucose homeostasis. Preliminary studies with liver and muscle, however, suggest that similar insulin-like effects of the antibodies will be seen. ${ }^{8}$ Perhaps, in vivo antibody binding mimics the effect of insulin to cause "down regulation" of insulin receptors $(35,36)$, and this in turn leads to insulin resistance and possibly even loss of the insulin-like effect of the antibody. Alternatively, the insulin-like effect of the antibodies may be prevented in vivo by some unknown underlying defect in the patient's own cells.

It is interesting to note that one of the three patients described in our initial report (patient B-2) has subsequently died with intractable hypoglycemia. During this terminal phase of her disease, circulating levels of

${ }^{6}$ Flier, J. S. Unpublished observation.

${ }^{7}$ Kahn, C. R., and K. Baird. Unpublished observation.

${ }^{8}$ Eisen, H., P. Freychet, J. Flier, and C. R. Kahn. Unpublished observation. 
immunoreactive insulin were low, but [125I]insulin binding to her cells had increased despite continued presence of the antireceptor antibody. It seems possible that in this patient in this stage of her disease, and perhaps in other patients with idiopathic hypoglycemia, anti-insulin receptor antibodies produce an insulin-like effect in vivo.

The effects of anti-insulin receptor antibodies on insulin binding and glucose oxidation are very similar to the effects reported for immunoglobulin fractions from patients with Graves' disease. Several laboratories have now reported that serum and immunoglobulin fractions from patients with Graves' disease can inhibit the binding of labeled thyroid-stimulating hormone (TSH) to thyroid membranes $(23,24,37,38)$. In addition, these same preparations stimulate the adenylate cyclase activity in thyroid tissue $(23,24,39-41)$ and, when administered in vivo, stimulate thyroid hormone secretion $(42,43)$. As with the anti-insulin receptor antibodies described in this report, immunoglobulins from patients with Graves' disease show heterogeneity with respect to titer, differing specificity for TSH receptors of various species, and ability to stimulate adenylate cyclase once bound to the receptor $(23,24,40)$.

Antibodies to the acetylcholine receptor have been found in the serum of patients with myasthenia gravis $(25-28,44)$ and in the serum of animals immunized with solubilized acetylcholine receptors $(45,46)$. In contrast to the antibodies to the insulin and TSH receptors, these appear to alter acetylcholine receptor function without major alterations in the binding of $\alpha$-bungarotoxin to the cholinergic binding site $(26,28$, 44). Antibodies to the prolactin receptor have been produced by immunization of guinea pigs with soluble prolactin receptor preparations (47). These antireceptor antibodies block both labeled prolactin binding and prolactin-stimulated biological effects in isolated mammary explants.

From these studies, it is clear that membrane receptor function can be altered in multiple ways by antibodies. In some cases, hormone binding is decreased and biological effects of the hormone are blocked; in other cases, the antibody blocks hormone binding and mimics its biological effect; and in still others, biological response is altered without an alteration in hormone binding. Antibodies to the insulin receptor show to some extent each of these functions. Thus, these antireceptor autoantibodies provide unique probes of both receptor structure and function.

\section{ACKNOWLEDGMENTS}

We wish to acknowledge Dr. Pierre De Meyts for help in data analysis, Dr. Jesse Roth for his advice and suggestions throughout this study, and Dr. Phillip Gorden for review of the manuscript. We also wish to thank Mses. C. Shinn, J. Smith, and D. Beall for secretarial assistance. Dr. David B. Jarrett is a recipient of a Clinical Sciences Fellowship from the National Health and Medical Research Council of Australia.

\section{REFERENCES}

1. Kahn, C. R., J. S. Flier, R. S. Bar, J. A. Archer, P. Gorden, M. M. Martin, and J. Roth. 1976. The syndromes of insulin resistance and acanthosis nigricans: insulin-receptor disorders in man. N. Engl. J. Med. 294: 739-745.

2. Flier, J. S., C. R. Kahn, J. Roth, and R. S. Bar. 1975. Antibodies that impair insulin receptor binding in an unusual diabetic syndrome with severe insulin resistance. Science (Wash. D.C.). 190: 63-65.

3. Flier, J. S., C. R. Kahn, D. B. Jarrett, and J. Roth. 1976. Characterization of antibodies to the insulin receptor. A cause of insulin-resistant diabetes in man. J. Clin. Invest. 58: 1442-1449.

4. Freychet, P., C. R. Kahn, J. Roth, and D. M. Neville, Jr. 1972. Insulin interactions with liver plasma membranes: independence of binding of the hormone and its degradation. J. Biol. Chem. 247: 3953-3961.

5. Roth, J. 1975. Methods for assessing immunologic and biologic properties of iodinated peptide hormones. Methods Enzymol. 37: 223-232.

6. Rodbell, M. 1964. Metabolism of isolated fat cells. I. Effects of hormones on glucose metabolism and lipolysis. J. Biol. Chem. 239: 375-380.

7. Entenman, C. 1957. General procedures for separating lipid components of tissue. Methods Enzymol. 3: 311317.

8. Lawrence, J. C., J. J. Guinovart, and J. Larner. 1977. Activation of rat adipocyte glycogen synthase by insulin. J. Biol. Chem. 252: 444-450.

9. Olefsky, J. M. 1975. Effect of dexamethasone on insulin binding, glucose transport, and glucose oxidation of isolated rat adipocytes. J. Clin. Invest. 56: 1499-1508.

10. Gammeltoft, S., and J. Gliemann. 1973. Binding and degradation of ${ }^{125} \mathrm{I}$-labeled insulin by isolated rat fat cells. Biochim. Biophys. Acta. 320: 16-32.

11. Jarrett, D. B., J. Roth, C. R. Kahn, and J. S. Flier. 1976. Direct method for detection and characterization of cell surface receptors for insulin by means of ${ }^{125}$ I-labeled autoantibodies to receptors. Proc. Natl. Acad. Sci. U.S.A. 73: 4115-4119.

12. Flier, J. S., C. R. Kahn, D. B. Jarrett, and J. Roth. 1977. Antibodies to the insulin receptor: effect on the insulinreceptor interaction in lymphocytes. J. Clin. Invest. 60: 784-794.

13. Fahey, J. L., and E. W. Terry. 1973. In Immunochemistry. D. M. Weir, editor. Blackwell Scientific Publications, Ltd., Oxford. Vol. 1. 71-74.

14. Stanworth, D. R., and M. W. Turner. 1973. Immunochemical analysis of immunoglobulins and their subunits. In Immunochemistry. D. M. Weir, editor. Blackwell Scientific Publications, Ltd., Oxford. 2nd edition. 10.010.97 .

15. Scatchard, G. 1949. The attractions of proteins for small molecules and ions. Ann. N. Y. Acad. Sci. 51: 660-672.

16. De Meyts, P., J. Roth, D. M. Neville, Jr., J. R. Gavin, III, and M. A. Lesniak. 1973. Insulin interactions with its receptors: experimental evidence for negative cooperativity. Biochem. Biophys. Res. Commun. 55: 154-161.

17. De Meyts, P., A. R. Bianco, and J. Roth. 1976. Site-site interactions among insulin receptors: characterization of the negative cooperativity. J. Biol. Chem. 251: 18771888.

18. Ginsberg, B. H., C. R. Kahn, J. Roth, and P. De Meyts. 1976. Insulin-induced dissociation of its receptor into sub- 
units: possible molecular concomitant of negative cooperativity. Biochem. Biophys. Res. Commun. 73: 10681074.

19. De Meyts, P., and J. Roth. 1975. Cooperativity in ligand binding: a new graphic analysis. Biochem. Biophys. Res. Commun. 55: 1118-1125.

20. De Meyts, P. 1976. The negative cooperativity of the insulin receptor: mathematical linkage of affinity to receptor occupancy and subunit structure. Abstracts of the 58th Annual Meeting of the Endocrine Society, 23-25 June 1976, San Francisco, Calif. 68.

21. Kono, T., and F. W. Barham. 1971. The relationship between the insulin-binding capacity of fat cells and the cellular response to insulin. Studies with intact and trypsin-treated fat cells. J. Biol. Chem. 246: 6210-6216.

22. Cuatrecasas, P., and G. Illiano. 1971. Membrane sialic acid and the mechanism of insulin action in adipose tissue cells. Effects of digestion with neuraminidase.J. Biol. Chem. 246: 4938-4946.

23. Smith, B. R., and R. Hall. 1974. Thyroid stimulating immunoglobulins in Graves' disease. Lancet. II: 427-430.

24. Mukhtar, E. D., B. R. Smith, G. A. Pyle, R. Hall, and P. Vice. 1975. Relation of thyroid-stimulating immunoglobulins to thyroid function and effects of surgery, radioiodine, and anti-thyroid drugs. Lancet. I: 713-715.

25. Almon, R. R., C. G. Andrew, and S. H. Appel. 1974. Serum globulin in myasthenia gravis: inhibition of $\alpha$-Bungarotoxin binding to acetylcholine receptors. Science (Wash. D. C.). 186: 55-57.

26. Abaronov, A., O. Abramsky, R. Tarrab-Haydai, and S. Fuchs. 1975. Hormonal antibodies to acetylcholine receptor in patients with myasthenia gravis. Lancet. I: $340-$ 342.

27. Bender, A. N., S. P. Ringel, W. K. Engel, M. P. Daniels, and $\mathrm{Z}$. Vogel. 1975. Myasthenia gravis: a serum factor blocking acetylcholine receptors of the human neuromuscular junction. Lancet. I: 607-609.

28. Lindstrom, J. M., M. E. Seybold, V. A. Lennon, S. Wittingham, and P. D. Duane. 1976. Anti acetylcholine receptor antibody in myasthenia gravis: incidence, chemical correlates and usefulness as a diagnostic test. Neurology. 26: 1054-1059.

29. Field, J. R., P. Johnson, and B. Herring. 1961. Insulinresistant diabetes associated with increased endogenous plasma insulin followed by complete remission. J. Clin. Invest. 40: 1672-1683.

30. Flier, J. S., E. Maratos-Flier, K. L. Baird, and C. R. Kahn. 1977. Antibodies to insulin receptor that block insulin binding fail to inhibit insulin degradation. Diabetes. 26(Suppl. 1): 354.

31. Czech, M. P., and W. S. Lynn. 1973. Stimulation of glucose metabolism by lectins in isolated white fat cells. Biochim. Biophys. Acta. 297: 368-377.

32. Cuatrecasas, P., and G. P. E. Tell. 1973. Insulin-like activity of concanavalin $A$ and wheat germ agglutinin: direct interactions with insulin receptors. Proc. Natl. Acad. Sci. U. S. A. 70: 485-489.
33. De Meyts, P., J. R. Gavin, III, J. Roth, and D. M. Neville, Jr. 1974. Concanavalin A: an inhibitor of cooperative interactions among insulin receptors. Diabetes. 23(Suppl. 1): 355 .

34. Crothers, D. M., and H. Metzger. 1972. The influence of polyvalency on the binding properties of antibodies. Immunochemistry. 9: 341-357.

35. Gavin, J. R., III, J. Roth, D. M., Neville, Jr., P. De Meyts, and D. N. Buell. 1974. Insulin-dependent regulation of insulin receptor concentrations: a direct demonstration in cell culture. Proc. Natl. Acad. Sci. U. S. A. 71: 84-88.

36. Kahn, C. R., K. Megyesi, R. S. Bar, R. C. Eastman, and J. S. Flier. 1977. Receptors for peptide hormones: new insights to the pathophysiology of disease states in man. Ann. Intern. Med. 86: 205-219.

37. Manley, S. W., J. R. Bourke, and R. W. Hawkins. 1974. The thyrotropin receptor in guinea-pig thyroid homogenate: interaction with the long-acting thyroid stimulator. J. Endocrinol. 61: 437-445.

38. O'Donnell, J., J. Silverberg, V. V. Row, and R. Volpe. 1976. Thyrotropin-displacing activity (TDA) of serum immunoglobulins in Graves' disease. Abstracts of the 58th Annual Meeting of the Endocrine Society, 23-25 June 1976, San Francisco, Calif. 367.

39. Mehdi, S. Q., and S. S. Nussey. 1975. A radio-ligand receptor assay for the long-acting thyroid stimulator. Biochem. J. 145: 105-111.

40. Orgiazzi, J., D. E. Williams, I. J. Chopra, and D. Solomon. 1976. Human thyroid adenylcyclase-stimulating activity of immunoglobulin G of patients with Graves' disease. J. Clin. Endocrinol. Metab. 42: 341-354.

41. Yamashita, K., and J. B. Field. 1972. Effects of long acting thyroid stimulator on thyrotropin stimulation of adenyl cyclase activity in thyroid plasma membranes. J. Clin. Invest. 51: 463-472.

42. Kress, J. P., V. Pleshakov, and J. R. Chien. 1964. Isolation and identification of the long acting thyroid stimulator and its relation to hyperthyroidism and circumscribed pretibial myxedema. J. Clin. Endocrinol. Metab. 24: 1005-1028.

43. McKenzie, J. M. 1972. Does LATS cause hyperthyroidism in Graves' disease? (A review biased toward the affirmative.) Metab. Clin. Exp. 21: 883-894.

44. Mittag, T., P. Kornfield, A. Tormay, and C. Woo. 1976. Detection of anti-acetylcholine receptor factors in serum and thymus from patients with myasthenia gravis. N. Engl. J. Med. 294: 691-694.

45. Patrick, J., and J. Lindstrom. 1973. Autoimmune response to acetylcholine receptor. Science (Wash. D. C.). 180: 871-872.

46. Tanab-Haydai, R., A. Abaronov, I. Silman, and S. Fuchs. 1975. Experimental autoimmune myasthenia induced in monkeys by purified acetylcholine receptors. Nature (Lond.). 256: 128-130, 1975.

47. Shiu, R. P. C., and H. G. Friesen. 1976. Blockade of prolactin action by an antiserum to its receptors. Science (Wash. D. C.). 192: 259-261. 